\title{
PENGARUH DIVIDEN PER SHARE (DPS), DIVIDEN PAYOUT RATIO (DPR), PRICE TO BOOK VALUE (PBV), DEBT TO EQUITY RATIO (DER), NET PROFIT MARGIN (NPM) DAN RETURN ON ASSET (ROA)TERHADAP HARGA SAHAM PADA PERUSAHAAN MANUFAKTUR SUB SEKTOR MAKANAN DAN MINUMAN DALAM KEMASAN YANG TERDAFTAR DI BEI
}

\author{
Edhi Asmirantho $^{*}$ dan Elif Yuliawati ${ }^{* *}$
}

\begin{abstract}
ABSTRAK
Penelitian ini dilakukan dengan tujuan untuk menguji pengaruh DPS, DPR, PBV, DER, NPM dan ROA terhadap harga saham pada perusahaan manufaktur sub sektor makanan dan minuman dalam kemasan yang terdaftar di Bursa Efek Indonesia. Teknik penelitian yang digunakan adalah purposive sampling dengan kriteria: (1) Perusahaan aktif yang terdaftar di Bursa Efek Indonesia berturut-turut selama tujuh tahun. (2) Perusahaan tersebut secara periodik menerbitkan laporan keuangan yaitu periode dari tahun 2007-2013. (3) Setiap perusahaan memiliki kelengkapan data yang dibutuhkan dalam penelitian. (4) Perusahaan secara rutin membagikan dividen selama tujuh periode. Teknik analisis yang digunakan adalah regresi linier berganda dan uji hipotesis menggunakan t-statistik untuk menguji koefisien regresi parsial serta F-statistik untuk menguji pengaruh secara simultan dengan tingkat kepercayaan 5\%. Selain itu semua variabel telah diuji dengan uji asumsi klasik. Hasil penelitian menunjukkan bahwa semua variabel lolos uji asumsi klasik dan layak digunakan sebagai data penelitian. Hasil uji t statistik menunjukan bahwa variable PBV, NPM dan ROA secara parsial berpengaruh positif dan signifikan terhadap harga saham, variabel lain dalam penelitian ini yaitu DPR berpengaruh negatif dan tidak signifikan. DPS dan DER tidak berpengaruh dan signifikan terhadap harga saham.Hasil uji F menunjukan bahwa semua variabel dalam penelitian ini berpengaruh positif dan signifikan terhadap harga saham. Hasil estimasi regresi menunjukkan kemampuan prediksi dari semua variabel independen tersebut terhadap harga saham sebesar $91,1 \%$. Sedangkan sisanya sebesar 8,9\% dipengaruhi oleh faktor lain diluar penelitian ini. Hasil ini dapat digunakan untuk memandu para investor sebelum menanamkan modal dipasar saham.

Kata Kunci: Dividen Per Share (DPS), Dividen Payout Ratio (DPR), Price to Book Value (PBV), Debt to Equity Ratio (DER), Net Profit Margin (NPM), dan Return On Asset (ROA).
\end{abstract}

\begin{abstract}
This research was conducted in order to test the influence of DPS, DER, PBV, DER, NPM and ROA on stock prices in the manufacturing sub-sectors of food and beverages in containers that are listed in the Indonesia Stock Exchange. The research technique that used was purposive sampling with criteria: (1) The Company actively listed on the Indonesia Stock Exchange for seven consecutive years. (2) The Company periodically publish financial statements of the period from 2007 to 2013. (3) Each company has a complete data needed in the research. (4) The Company regularly distribute dividends for seven period. The analysis technique that used was multiple linear regression and hypothesis testing using tstatistic to test the partial regression coefficient and F-statistic to test the effect simultaneously with a confidence level of 5\%. Besides all the variables have been tested with the classical assumption. The results of this research showed that all variables passed the test classic assumptions and fit for use as research data. Statistical t test results showed that the variables PBV, NPM and ROA were partial positive and significant impact on stock prices, other variables in this research that the Parliament has negative and insignificant. DPS and DER have no effect and significant to price stock. The results of F test showed that all variables in this study positive and significant effect on the price stock. The results of regression estimation shows the predictive capability of all independent variables on stock prices by $91.1 \%$. While the rest of $8.9 \%$ influenced by other factors beyond this research. These results can be used to guide the investors before investing the stock market.

Keywords: Dividend Per Share (DPS), Dividend Payout Ratio (DPR), Price to Book Value (PBV), Debt to Equity Ratio (DER), Net Profit Margin (NPM), and Return on Assets (ROA).
\end{abstract}

\footnotetext{
${ }^{*}$ Dosen Tetap Fakultas Ekonomi Universitas Pakuan

${ }^{* *}$ Mahasiswa Fakultas Ekonomi Universitas Pakuan
} 


\section{Pendahuluan}

Harga saham yang mengalami kenaikan mempunyai dampak baik terhadap perusahaan karena dapat meningkatkan nilai saham, sebaliknya akan berdampak buruk pada modal perusahaan karena modal tersebut tidak akan bertambah dan akan berhenti karena saham tersebut tidak laku dan banyak investor ingin menjual sahamnya. Sehingga transaksi pasar menjadi lemah karena harga saham yang mahal dan kemampuan investor untuk membeli saham dengan harga tinggi yang terbatas. Harga saham yang baik yaitu harga saham yang bergerak fluktuatif. (Jogiyanto 2000;8)

Rasio pertama yang diperkirakan mempengaruhi harga saham yaitu Dividen Per Share (DPS).

Menurut Keown dan Scott (2000;629) Dividen Per Share (DPS) adalah untuk menunjukan seluruh pembiayaan deviden dalam angka per saham.

Dalam hipotesis kandungan informasi (information signaling content), dividen yang dibagikan dapat memberikan efek terhadap harga saham perusahaan karena dalam pengumuman pembagian dividen mengandung informasi yang penting bagi investor sebagai sinyal dari perusahaan mengenai prospek perusahaan di masa depan. Perusahaan yang Dividen per Share lebih tinggi dibandingkan dengan perusahaan perusahaan sejenis akan lebih diminati oleh investor, karena investor akan memperoleh kepastian modal yang ditanamkannya, yaitu hasil berupa dividen. (Brigham dan Houston 2006:76)

Rumus yang digunakan dalam perhitungan Dividen Per Share (DPS).

$(\mathrm{DPS})=\frac{\text { Total Dividen } \text { Paid }}{\text { Number of Ordinary Share in Issued }}$
Teori tersebut diperkuat dengan penelitian Priantinah dan Adhe (2012), Hutami (2012) dan Djonysan (2014) menyimpulkan bahwa rata-rata harga saham meningkat setelah pembagian dividen. Berdasarkan beberapa pendapat tersebut dapat dikatakan bahwa kebijakan perusahaan dalam membagikan dividen dapat meningkatkan harga sahamnya. Dividen yang dibagikan oleh perusahaan dapat berupa dividen saham atau dividen tunai. Dividen tunai merupakan salah satu dividen yang dibagikan oleh perusahaan. sehingga Dividen Per Share (DPS) berpengaruh positif terhadap harga saham.

Rasio kedua yang diperkirakan mempengaruhi harga saham yaitu Dividen Payout Ratio (DPR) yaitu rasio yang menentukan jumlah laba yang dapat ditahan sebagai sumber pendanaan serta menunjukkan persentase laba perusahaan yang dibayarkan ke pemegang saham dalam bentuk kas.

Menurut Brigham dan Houston, (1999) makin tinggi tingkat deviden yang dibayarkan, berarti makin sedikit laba yang ditahan, dan sebagai akibatnya ialah menghambat tingkat pertumbuhan dalam pendapatan dan harga sahamnya. Oleh karena itu Dividen Payout Ratio (DPR) berpengaruh negatif terhadap harga saham.

Rumus yang digunakan dalam perhitungan Dividen Payout Ratio (DPR).

$(\mathrm{DPR})=\frac{\text { Dividen } \text { per share }}{\text { Earning per share }}$

Teori tersebut sejalan dengan penelitian yang dilakukan oleh Natarsyah (2000) hasil penelitian yg diperoleh menyatakan bahwa Dividen 
Payout Ratio (DPR) berpengaruh negatif terhadap harga saham.

Rasio ketiga yang diperkirakan mempengaruhi harga saham yaitu Price To Book Value (PBV). Menurut Tandelilin (2001;194) Price to Book Value (PBV) adalah Hubungan antara harga pasar saham dan nilai buku per lembar saham bisa juga dipakai sebagai pendekatan alternatif untuk menentukan nilai suatu saham, karena secara teoritis, nilai pasar suatu saham haruslah mencerminkan nilai bukunya.

Rumus yang digunakan dalam perhitungan Price To Book Value(PBV) menurut John, Subramanyam dan Halsey (2005):

$(\mathrm{PBV})=\frac{\text { Market price per share }}{\text { Book value per share }}$

Dalam penelitian Putu dan Suaryana (2013) dan Asmirantho (2014) PBV mencerminkan tingkat keberhasilan manajemen perusahaan dalam menjalankan perusahaan, mengelola sumber daya yang tercermin pada harga saham pada akhir tahun. Semakin tinggi nilai PBV tentunya memberikan harapan para investor untuk mendapatkan keuntungan yang lebih besar.Oleh karena itu PBV berpengaruh positif dan signifikan terhadap harga saham. Tetapi berbeda dengan penelitian yang dilakukan oleh Stella bahwa PBV berpengaruh negatif terhadap harga saham.

Rasio keempat yang diperkirakan mempengaruhi harga saham yaitu Debt To Equity Ratio (DER) dimana rasio ini disebut juga sebagai rasio yang melihat perbandingan hutang perusahaan, yaitu diperoleh dari perbandingan total hutang dibagi total aset. Semakin rendah semakin baik karena aman bagi kreditor saat likuidasi. Bagi perusahaan, sebaiknya besarnya hutang tidak boleh melebihi modal sendiri agar beban tetapnya tidak terlalu tinggi.
Rumus yang digunakan dalam perhitungan Debt To Equity Ratio(DER) menurut Van Horne dan Wachowicz (1998):

$$
(\mathrm{DER})=\frac{\text { Total debt }}{\text { Shareholders' equity }}
$$

DER yang rendah akan meningkatkan respon positif dari pasar dan akan semakin baik kemampuan perusahaan dalam membayar kewajiban jangka panjang karena risiko yang ditimbulkan dari penggunaan pendanaan yang bersumber dari hutang akan berkurang, sehingga saham naik. Oleh karena itu, DER memiliki pengaruh negatif terhadap harga saham (Brigham dan Houston, 2006:104).

Teori ini didukung dengan penelitian Stella (2009), Putu dan Suaryana (2013) dan Asmirantho (2014) yang menyatakan bahwa DER berpengaruh negatif terhadap harga saham.

Rasio kelima yang diperkirakan mempengaruhi harga saham yaitu Net Profit Margin (NPM) merupakan rasio antara laba bersih setelah pajak atau net income after tax (NIAT) dengan net sales.Semakin besar nilai NPM menunjukkan tingginya kemampuan perusahaan dalam menghasilkan laba bersih. Dengan kemampuan perusahaan dalam menghasilkan laba bersih yang semakin tinggi, diharapkan mampu memberikan pengaruh positif terhadap harga saham (Ang, Robert 1997).

Rumus yang digunakan dalam perhitungan Net Profit Margin (NPM) menurut Brigham dan Houston (2006;107):

$$
(\mathrm{NPM})=\frac{\text { Net } \text { Profit }}{\text { Sales }}
$$

Dalam penelitian Rescyana (2012) NPM yang tinggi memberikan sinyal akan keberhasilan perusahaan dalam mengemban misi dari pemiliknya. Perusahaan yang mampu menghasilkan 
keuntungan akan mempengaruhi investor atau calon investor untuk melakukan investasi. Investor akan bersedia membeli saham dengan harga lebih tinggi apabila memperkirakan tingkat NPM perusahaan naik, dan sebaliknya investor tidak bersedia membeli saham dengan harga tinggi apabila nilai NPM perusahaan rendah. Berbeda dengan penelitian Diah Prameswari (2014) yang mendapat hasil bahwa NPM tidak berpengaruh dan signifikan terhadap harga saham.

Rasio keenam yang diperkirakan mempengaruhi harga saham yaitu Return On Asset (ROA). Menurut James M. Reeve yang dialih bahasakan oleh Damayanti(2010:332) Return On Asset (ROA) merupakan ukuran profitabilitas yang menunjukkan efektivitas sebuah perusahaan dalam memanfaatkan asetnya.

Rumus yang digunakan dalam perhitungan Return On Asset menurut Van Horne dan Wachowicz (1998) :

$$
(\mathrm{ROA})=\frac{\text { Net } \text { Prof it } \text { After } T a x}{\text { Total Asset }}
$$

Dalam penelitiannya Meilinda dan Endang (2012) hasil pengembalian total aktiva atau total investasi menunjukkan kinerja manajemen dalam menggunakan aktiva perusahaan untuk menghasilkan laba. Perusahaan mengharapkan adanya pengembalian yang sebanding dengan dana yang digunakan. Hasil pengembalian ini dapat dibandingkan dengan penggunaan alternatif dari dana tersebut. Sebagai salah satu ukuran keefektifan, maka semakin tinggi hasil pengembalian, semakin efektiflah perusahaan. Efektivitas kinerja perusahaan dapat mempengaruhi harga saham perusahaan.

Penelitian yang dilakukan Stella (2009), Asmirantho (2014) dan Prameswari (2014) ROA tidak berpengaruh terhadap harga saham.
Berbeda dengan Natarsyah (2000) berpengaruh positif dan signifikan terhadap harga saham.

\section{HIPOTESIS PENELITIAN}

Berdasarkan kerangka pemikiran diatas maka penulis mencoba merumuskan hipotesis sebagai berikut :

H1: Dividen Per Share (DPS) berpengaruh positif terhadap Harga Saham.

H2: Dividen Payout Ratio (DPR) berpengaruh negatif terhadap Harga Saham.

H3: Price To Book Value (PBV) berpengaruh positif terhadap Harga Saham.

H4: Debt To Equity Ratio (DER) berpengaruh negatif terhadap Harga Saham.

H5: Net Profit Margin (NPM) berpengaruh positif terhadap Harga Saham.

H6: Return On Asset (ROA) berpengaruh positif terhadap Harga Saham.

H7: Terdapat pengaruh Dividen Per Share (DPS), Dividen Payout Ratio (DPR), Price to Book Value (PBV), Debt to Equity Ratio (DER), Net Profit Margin (NPM) dan Return On Asset (ROA) secara simultan terhadap Harga Saham.

\section{OBJEK DAN METODE PENELITIAN \\ Jenis Penelitian}

Jenis penelitian yang digunakan dalam penelitian ini adalah jenis penelitian kuantitatif, yaitu jenis penelitian yang bertujuan untuk mengetahui pengaruh antara variabel $\mathrm{X}$ (independent variabel/variabel bebas) terbagi dalam enam unsur, yaitu X1 adalah Dividen Per Share (DPS), X2 adalah Dividen Payout Ratio (DPR), X3 adalah Price to Book Value (PBV), X4 adalah Debt to Equity Ratio (DER), X5 adalah Net 
Profit Margin (NPM), dan X6 adalah Return On Asset (ROA) terhadap variabel Y (dependent variabel/variabel terikat) adalah Harga Saham (Closing Price).

\section{Objek Penelitian}

Dalam penelitian ini perusahaan yang dijadikan objek penelitian yaitu perusahaan Manufaktur Sub Sektor Makanan dan Minuman dalam kemasan tahun 2007-2013.

\section{Unit Analisis}

Unit analisis merupakan tingkat agregasi data yang dianalisis dalam suatu penelitian. Unit analisis yang digunakan dalam penelitian ini adalah unit analisis organization, yaitu data yang dihasilkan berasal dari respon suatu organisasi tertentu.

\section{Lokasi Penelitian}

Lokasi penelitian ini berlokasi pada Perusahaan Manufaktur Sub Sektor Makanan dan Minuman dalam kemasan yang terdaftar di Bursa Efek Indonesia (BEI) atau Indonesia Stock Exchange (IDX).

\section{Jenis dan Sumber Data Penelitian}

Jenis data dalam penelitian ini adalah jenis data kuantitatif yang merupakan data sekunder. Data sekunder adalah data yang diperoleh peneliti secara tidak langsung, tetapi diperoleh dari penyedia data, bursa efek, data yang digunakan peneliti dalam penelitian sebelumnya. Data sekunder dalam penelitian ini diperoleh melalui situs internet Bursa Efek Indonesia (BEI) yaitu www.idx.co.id.

\section{Metode Penarikan Sampel}

Dalam penelitian ini perusahaan yang menjadi subjek penelitian adalah perusahaan manufaktur yang bergerak di bidang makanan dan minuman dalam kemasan yang terdaftar di Bursa Efek Indonesia (BEI) tahun 2007-2013 dengan total perusahaan sebanyak 16 perusahaan. Dalam pemilihan sampel perusahaan yang digunakan dalam penelitian ini adalah metode purposive sampling yang dimana teknik penarikan sampel dengan pertimbangan tertentu dan diperoleh sampel penelitian yang memenuhi kriteria yaitu sebanyak 8 perusahaan.

Adapun kriteria yang digunakan dalam pemilihan sampel dalam penelitian ini adalah:

1) Perusahaan yang terdaftar di Bursa Efek Indonesia Sub Sektor Makanan dan Minuman dalam kemasan selama tujuh tahun berturut-turut dari tahun 2007 sampai dengan tahun 2013.

2) Perusahaan tersebut secara periodik menerbitkan laporan keuangan selama periode penelitian yaitu dari tahun 2007 sampai dengan tahun 2013.

3) Setiap perusahaan yang dijadikan sampel penelitian, memiliki kelengkapan data yang dibutuhkan dalam penelitian.

4) Perusahaan yang dijadikan sampel membagikan dividen berturutturut selama periode penelitian tahun 2007 sampai dengan tahun 2013.

Uji Regresi Linier Berganda

$$
Y=a+b_{1} X_{1}+b_{2} X_{2}+b_{3} X_{3}+b_{4} X_{4}+
$$$$
b_{5} X_{5}+b_{6} X_{6}+e
$$

$$
\begin{array}{ll}
\text { Keterangan : } & \\
\mathrm{Y} & =\text { Harga Saham } \\
\mathrm{a} & =\text { Konstanta } \\
\mathrm{X}_{1} & =\mathrm{DPS} \\
\mathrm{X}_{2} & =\mathrm{DPR} \\
\mathrm{X}_{3} & =\mathrm{PBV} \\
\mathrm{X}_{4} & =\mathrm{DER} \\
\mathrm{X}_{5} & =\mathrm{ROA} \\
\mathrm{X}_{6} & =\text { Koefisien Regresi } \\
\mathrm{b}_{1} \text { sampai } \mathrm{b}_{6} & \\
\mathrm{e} & =\text { Error Term. }
\end{array}
$$

\section{HASIL PENELITIAN \\ Deskriptif Statistik Variabel \\ Penelitian}


Tabel 4.14

Hasil Analisis Deskriptif Data

The Results of Descriptive Analysis Data

\begin{tabular}{|c|c|c|c|c|c|}
\hline & $\mathrm{N}$ & Minimum & Maximum & Mean & Std. Deviation \\
\hline Harga saham & 56 & 75,00 & 1200000,00 & 72464,0357 & 199704,63463 \\
\hline DPS & 56 &, 00 & 247,91 & 31,3845 & 57,07980 \\
\hline DPR & 56 & ,00 & 754,77 & 51,2361 & 115,89092 \\
\hline PBV & 56 &, 34 & 47,27 & 5,5291 & 8,37985 \\
\hline DER & 56 & ,20 & 8,44 & 1,2580 & 1,18763 \\
\hline ROA & 56 & 2,23 & 79,83 & 12,4779 & 13,97608 \\
\hline NPM & 56 & 1,42 & 100,02 & 11,8654 & 14,46056 \\
\hline $\begin{array}{ll}\text { Valid } & \mathrm{N} \\
\text { (listwise) } & \end{array}$ & 56 & & & & \\
\hline
\end{tabular}

(Sumber : Diolah SPSS)

Berdasarkan tabel 4.14 diketahui bahwa jumlah sampel data dalam penelitian ini adalah sebanyak 56 sampel data. Berdasarkan hasil perhitungan selama periode tahun 2007-2013 terlihat bahwa harga saham (closing price) terendah (minimum) adalah 75 dan harga saham (closing price) tertinggi (maximum) adalah 1200000. Rata-rata (mean) harga saham (closing price) adalah sebesar 72464,0357 atau $7246403,57 \%$, dapat diketahui harga saham pada sampel perusahaan yang menjadi sampel dalam penelitian ini mengalami peningkatan pada setiap tahunnya. Standar deviasi harga saham (closing price) sebesar 199704,63463 atau $19970463,463 \%$ ini menunjukkan bahwa variabel harga saham memiliki sebaran luas karena memiliki standar deviasi lebih besar dari meannya.

Data Dividen Per Share (DPS) terendah (minimum) sebesar 0.00 atau $0 \%$ dan tertinggi (maximum) sebesar 247,91 atau $24791 \%$. Kemudian rata-rata (mean) sebesar 31,3845 atau $3138,45 \%$ dengan nilai standar deviasi 57,07980 atau $5707,980 \%$ karena nilai standar deviasi lebih besar dari rata-rata (mean) dapat
disimpulkanDividen Per Share (DPS) memiliki sebaran yang cukup besar.

Data Dividen Payout Ratio (DPR) terendah (minimum) sebesar 0.00 atau $0 \%$ dan tertinggi (maximum) sebesar 754,77 atau $75477 \%$. Dengan rata-rata (mean) sebesar 51,2361 atau 5123,61\% dan standar deviasinya adalah sebesar 115,89092 atau $11589,092 \%$. Sehingga dapat diketahui bahwa Dividen Payout Ratio (DPR) memiliki sebaran yang luas karena standar deviasi lebih besar dari mean nya.

Data Price to Book Value (PBV) terendah (minimun) adalah sebesar 0,34 atau $34 \%$ dan tertinggi (maximum) adalah sebesar 47,27 atau $4727 \%$. Dengan rata-rata (mean) sebesar 5,5291 atau $552,91 \%$ dan standar deviasinya 8,37958 atau $837,958 \%$. Sehingga dapat diketahui bahwa Price to Book Value (PBV) memiliki sebaran yang cukup luas karena standar deviasi lebih besar dari mean nya.

Data Debt to Equity Ratio (DER) terendah (minimum) adalah sebesar 0,20 atau $20 \%$ dan tertinggi (maximum) adalah sebesar 8,44 atau $844 \%$. Dengan rata-rata (mean) sebesar 1,2580 atau $125,80 \%$ dan standar deviasinya adalah sebesar 1,18763 atau $118,763 \%$. 
Sehingga dapat disimpulkan bahwa Debt to Equity Ratio (DER) bagus karena standar deviasi lebih kecil dari pada mean.

Data Return On Asset (ROA) terendah (minimum) adalah sebesar 2,23 atau $223 \%$ dan tertinggi (maximum) adalah sebesar 79,83 atau 7983\%. Dengan ratarata (mean) sebesar 12,4779 atau $1247,79 \%$ dan standar deviasinya adalah 13,97608 atau $1397,608 \%$. Sehingga dapat disimpulkan bahwa Return On Asset (ROA) memiliki sebaran cukup besar karena standar deviasi lebih besar dari mean nya.

\section{Uji Normalitas}

Tabel 4.15
Data Net Profit Margin (NPM) terendah (minimum) adalah sebesar 1,42 atau $142 \%$ dan tertinggi (maximum) adalah sebesar 100,02 atau $10002 \%$. Dengan rata-rata (mean) sebesar 11,8654 atau $1186,54 \%$ dan standar deviasinya adalah sebesar 14,46056 atau 1446,056\%. Dapat disimpulkan bahwa Net Profit Margin (NPM) menunjukkan sebaran yang cukup besar karena standar deviasi lebih besar dari mean nya.

One Sample Kolmogorov Smirnov Test

\begin{tabular}{|c|c|c|}
\hline \multicolumn{3}{|c|}{ One-Sample Kolmogorov-Smirnov Test } \\
\hline & & $\begin{array}{l}\text { Unstandardized } \\
\text { Residual }\end{array}$ \\
\hline & $\begin{array}{l}56 \\
0 \mathrm{E}-7\end{array}$ \\
\hline Normal Parameters & $\begin{array}{l}\text { Std. } \\
\text { Deviation }\end{array}$ & 59449.04280644 \\
\hline \multirow{3}{*}{$\begin{array}{l}\text { Most } \quad \text { Extreme } \\
\text { Differences }\end{array}$} & Absolute & .061 \\
\hline & Positive & .047 \\
\hline & Negative & -.061 \\
\hline \multirow{2}{*}{\multicolumn{2}{|c|}{$\begin{array}{l}\text { Kolmogorov-Smirnov Z } \\
\text { Asymp. Sig. (2-tailed) }\end{array}$}} & .455 \\
\hline & & .986 \\
\hline
\end{tabular}

(Sumber : Data SPSS)

a. Test distribution is Normal.

b. Calculated from data.

Dari output tabel 4.15 dapat diketahui bahwa nilai signifikansi (Asymp. Sig. (2tailed) sebesar 0,986. Karena nilai signifikansi lebih besar dari 0,05 (0,986
$>0,05)$ maka nilai residual tersebut telah normal.

Uji

Moltikolineritas

Tabel 4.16

Nilai Tolerance dan Inflation Factor (VIF)

Tolerance Values and Inflation Factor (VIF)

Coefficients $^{\mathrm{a}}$

\begin{tabular}{|c|c|c|c|c|c|c|c|}
\hline \multirow[t]{2}{*}{ Model } & \multicolumn{2}{|c|}{$\begin{array}{l}\text { Unstandardized } \\
\text { Coefficients }\end{array}$} & $\begin{array}{l}\text { Standardized } \\
\text { Coefficients }\end{array}$ & \multirow[t]{2}{*}{$\mathrm{T}$} & \multirow[t]{2}{*}{ Sig. } & \multicolumn{2}{|c|}{ Collinearity Statistics } \\
\hline & B & Std. Error & Beta & & & Tolerance & VIF \\
\hline (Constant) & $-65247,120$ & 15949,410 & & $-4,091$ &, 000 & & \\
\hline
\end{tabular}

JIAFE (Jurnal Ilmiah Akuntansi Fakultas Ekonomi)

Volume 1 No. 2 Tahun 2015, Hal. 95-117 


\begin{tabular}{|c|c|c|c|c|c|c|c|}
\hline $\begin{array}{l}\text { Dividen } \\
\text { Per Share }\end{array}$ & 101,231 & 159,639 & ,029 & 634 & ,529 & ,869 & 1,151 \\
\hline $\begin{array}{l}\text { Dividen } \\
\text { Payout } \\
\text { ratio }\end{array}$ & $-3,783$ & 79,498 &,- 002 &,- 048 & 962 & ,850 & 1,177 \\
\hline $\begin{array}{ll}\text { Price } & \text { to } \\
\text { Book } & \\
\text { Value } & \end{array}$ & 10241,499 & 1659,658 & ,430 & 6,171 & ,000 &, 373 & 2,682 \\
\hline $\begin{array}{l}\text { Debt to } \\
\text { Equity } \\
\text { Ratio }\end{array}$ & $-31836,717$ & 8919,438 &,- 189 & $-3,569$ & , 001 & 643 & 1,556 \\
\hline $\begin{array}{l}\text { Net Profit } \\
\text { Margin }\end{array}$ & 6296,244 & 1202,631 & ,456 & 5,235 & ,000 & ,238 & 4,193 \\
\hline $\begin{array}{l}\text { Return On } \\
\text { Asset }\end{array}$ & 3481,858 & 1443,344 & ,244 & 2,412 & ,020 & ,177 & 5,642 \\
\hline
\end{tabular}

a. Dependent Variable: Harga Saham

(Sumber : Data SPSS)

Dari output tabel 4.16 dapat diketahui bahwa nilai tolerance keenam variabel independen yaitu dividen per share $(0,869)$, dividen payout ratio $(0,850)$, price to book value $(0,373)$, debt to equity ratio $(0,643)$, net profit margin
$(0,238)$, danreturn on asset $(0,177)$ kurang dari 10. Maka dapat disimpulkan bahwa tidak terjadi masalah multikolineritas pada model regresi.

\section{Uji Heteroskedastisitas}

Tabel 4.17

Uji Glejser

Table 4.17

Test of Glejser

Coefficients $^{\mathrm{a}}$

\begin{tabular}{|c|c|c|c|c|c|}
\hline \multirow[t]{2}{*}{ Model } & \multicolumn{2}{|c|}{ Unstandardized Coefficients } & \multirow{2}{*}{$\begin{array}{l}\text { Standardized } \\
\text { Coefficients } \\
\text { Beta }\end{array}$} & \multirow[t]{2}{*}{$\mathrm{t}$} & \multirow[t]{2}{*}{ Sig. } \\
\hline & $\mathrm{B}$ & Std. Error & & & \\
\hline (Constant) & 30024,885 & 8795,854 & & 3,414 & ,001 \\
\hline DPS & $-140,785$ & 88,038 &,- 214 & $-1,599$ & , 116 \\
\hline DPR & $-6,464$ & 43,842 &,- 020 &,- 147 & ,883 \\
\hline PBV & $-46,067$ & 915,276 &,- 010 &,- 050 & ,960 \\
\hline DER & 7415,767 & 4918,932 & ,235 & 1,508 & , 138 \\
\hline NPM & 1008,198 & 663,233 & ,388 & 1,520 & , 135 \\
\hline ROA & $-51,466$ & 795,982 &,- 019 &,- 065 & ,949 \\
\hline
\end{tabular}

a. Dependent Variable: ABS_RES

(Sumber : Data SPSS)

Berdasarkan output tabel 4.17 dapat diketahui bahwa nilai signifikansi keenam variabel independen yaitu dividen per share $(0,116)$, dividen payout ratio $(0,883)$, price to book value
$(0,960)$, debt to equity ratio $(0,138)$, net profit margin $(0,135)$ dan return on asset $(0,949)$ lebih dari 0,05. Dengan demikian dapat disimpulkan bahwa tidak 
terjadi masalah heteroskedastisitas pada model regresi.

\section{Uji Autokorelasi}

Tabel 4.18

Uji Durbin Watson

Table 4.18

Test of Durbin Watson

Model Summary ${ }^{b}$

\begin{tabular}{|l|l|l|l|l|l|}
\hline Model & R & R Square & $\begin{array}{l}\text { Adjusted } \\
\text { R Square }\end{array}$ & $\begin{array}{l}\text { Std. Error of } \\
\text { the Estimate }\end{array}$ & $\begin{array}{l}\text { Durbin- } \\
\text { Watson }\end{array}$ \\
\hline 1 &, $955^{\mathrm{a}}$ &, 911 &, 901 & 62983,70019 & 1,238 \\
\hline
\end{tabular}

a. Predictors: (Constant), Return On Asset, Dividen Per Share, Debt To Equity Ratio, Dividen Payout ratio, Price To Book Value, Net Profit Margin

b. Dependent Variable: Harga Saham

Berdasarkan tabel 4.18 diatas dapat diketahui nilai Durbin-Watson sebesar 1,238. Nilai DU dan DL dapat diperoleh tabel statistik Durbin - Watson dengan $\mathrm{n}=56$ dan $\mathrm{k}=$ 6 maka dapat nilai $\mathrm{DU}=1,8124$ dan $\mathrm{DL}=1,3424$. jadi didapat nilai 4 -DU $=2,1876$, dan nilai 4-DL= 2,6576. Karena nilai $\mathrm{DU}<\mathrm{DW}<4$-DU $=1,8124<1,238<2,1876$ maka dapat telah terjadi autokorelasi pada model regresi, untuk menguji kembali autokorelasi maka dilanjutkan menggunakan runs test. Hasil pengujian runs test dilihat pada tabel 4.19 .

Tabel 4.19.

Runs Test

\begin{tabular}{|l|l|}
\hline & $\begin{array}{l}\text { Unstandardized } \\
\text { Residual }\end{array}$ \\
\hline Test Value $^{\mathrm{a}}$ & 411.08663 \\
Cases $<$ Test Value & 28 \\
Cases $>=$ Test Value & 28 \\
Total Cases & 56 \\
Number of Runs & 23 \\
Z & -1.618 \\
Asymp. Sig. (2-tailed) & .106 \\
\hline
\end{tabular}

a. Median

Berdasarkan hasil uji runs test nilai signifikansi 0,106 > 0,05 maka dapat disimpulkan tidak terjadi autokorelasi. Setelah keempat uji asumsi klasik telah terpenuhi, maka dapat disimpulkan bahwa model regresi sudah memenuhi syarat yang artinya nilai residual terdistribusi normal, tidak adanya multikolinieritas, tidak adanya heteroskedastisitas, dan tidak adanya autokorelasi pada model regresi.

Uji Regresi Linier Berganda 
Tabel 4.20

Model Regresi

Table 4.20

Regression Model

Model Summary

\begin{tabular}{|l|l|l|l|l|}
\hline Model & R & R Square & $\begin{array}{l}\text { Adjusted R } \\
\text { Square }\end{array}$ & $\begin{array}{l}\text { Std. Error of } \\
\text { the Estimate }\end{array}$ \\
\hline 1 & $955^{\mathrm{a}}$ &, 911 &, 901 & 62983,70019 \\
\hline
\end{tabular}

a. Predictors: (Constant), Return On Asset, Dividen Per

Share, Debt To Equity Ratio, Dividen Payout ratio, Price To

Book Value, Net Profit Margin

Output tabel 4.20 menjelaskan tentang ringkasan model, yang terdiri dari hasil nilai korelasi sederhana $(\mathrm{R})$ sebesar 0,955 atau 95,5\%, koefisien determinasi ( $\mathrm{R}$ Square) sebesar 0,911 atau $91,1 \%$, koefisien determinasi yang disesuaikan (Adjusted R Square) sebesar 0,901 atau 90,1\%, dan ukuran kesalahan prediksi (Std Error of the estimate) sebesar 62983,70019 atau $6298370,019 \%$.

\section{Uji F}

Tabel 4.21

Uji F Statistika

Table 4.21

Test of F Statistics

ANOVA $^{\mathrm{a}}$

\begin{tabular}{|l|l|l|l|l|l|}
\hline \multicolumn{1}{|c|}{ Model } & Sum of Squares & Df & Mean Square & F & Sig. \\
\hline \multirow{4}{*}{$\begin{array}{l}\text { 1 Regression } \\
\text { Residual }\end{array}$} & 1999126382190,802 & 6 & 333187730365,134 & 83,991 &, $000^{\mathrm{b}}$ \\
\multicolumn{1}{|c|}{ Total } & 194380377983,127 & 49 & 3966946489,452 & & \\
\hline
\end{tabular}

a. Dependent Variable: Harga Saham

b. Predictors: (Constant), Return On Asset, Dividen Per Share, Debt to Equity Ratio, Dividen Payout ratio, Price to Book Value, Net Profit Margin

Dari output tabel 4.23 diperoleh F hitung sebesar 83,991. F tabel dapat dilihat pada tabel statistik distribusi $\mathrm{F}$ pada tingkat signifikansi 0,05 dengan $\mathrm{df}$ 1 (jumlah variabel-1) $=6$, dan df 2 (n-k1) atau 56-6-1 = 49 (n adalah jumlah data dan $\mathrm{k}$ adalah jumlah variabel independen), hasil diperoleh untuk $\mathrm{F}$ tabel sebesar 2,29. Karena hasil F hitung
$>\mathrm{F}$ tabel $(83,991>2,29)$ maka Ho ditolak. Jadi dapat disimpulkan bahwa antara Dividen Per Share (DPS), Dividen Payout Ratio (DPR), Price to book Value (PBV), Debt to Equity Ratio (DER), Net Profit Margin (NPM) dan Return On Asset (ROA) secara bersamasama berpengaruh signifikan terhadap hargasaham.

\section{Uji t}


Tabel 4.22

Uji t Satistika

Table 4.22

Test of $t$ Statistics

Coefficients $^{\mathrm{a}}$

\begin{tabular}{|l|l|l|l|l|l|}
\hline \multirow{2}{*}{ Model } & \multicolumn{2}{|l|}{$\begin{array}{l}\text { Unstandardized } \\
\text { Coefficients }\end{array}$} & $\begin{array}{l}\text { Standardized } \\
\text { Coefficients }\end{array}$ & \multirow{2}{*}{ Sig. } \\
\cline { 2 - 4 } & B & Std. Error & Beta & & \\
\hline (Constant) & $-65247,120$ & 15949,410 & & $-4,091$ &, 000 \\
DPS & 101,231 & 159,639 &, 029 &, 634 &, 529 \\
DPR & $-3,783$ & 79,498 &,- 002 &,- 048 &, 962 \\
1 PBV & 10241,499 & 1659,658 &, 430 & 6,171 &, 000 \\
DER & $-31836,717$ & 8919,438 &,- 189 & $-3,569$ &, 001 \\
NPM & 6296,244 & 1202,631 &, 456 & 5,235 &, 000 \\
ROA & 3481,858 & 1443,344 &, 244 & 2,412 &, 020 \\
\hline
\end{tabular}

a. Dependent Variable: Harga Saham (Sumber : Data SPSS)

Berdasarkan output 4.22 dapat dijelaskan bahwa harga saham 65247.120 ,Dividen Per Share (DPS) 101,231, Dividen Payout Ratio (DPR) 3,783, Price to Book Value (PBV) 10241,499, Debt to Equity Ratio (DER) 31836,717, Net Profit Margin (NPM) 6296,244 dan Return On Asset (ROA) 3481,858 .

a) Dari output 4.22 diperoleh nilai $\mathrm{t}$ hitung untuk Dividen Per Share (DPS) adalah 0,634. Karena nilai $\mathrm{t}$ hitung > $\mathrm{t}$ tabel $(0,634<$ 2,00958) maka Ho ditolak. Jadi dapat disimpulkan bahwa Dividen Per Share (DPS) secara parsial berpengaruh positif dan signifikan terhadap hargasaham.

b) Dari output 4.22 diperoleh nilai $t$ hitung untuk Dividen Payout Ratio (DPR) adalah -0,048. Karena nilai -t hitung < - t tabel ($0.048<-2,00958)$ maka Ho ditolak. Jadi dapat disimpulkan dividen payout ratio (DPR) secara parsial berpengaruh negatif dan tidak siginifikan terhadap harga saham. c) Dari output 4.22 diperoleh nilai t hitung untuk Price to Book Value (PBV)adalah 6,171. Karena nilai $\mathrm{t}$ hitung $>\mathrm{t}$ tabel $(6,171>$ 2,00958) maka Ho ditolak. Jadi dapat disimpulkan bahwa Price to Book Value (PBV) secara parsial berpengaruh positif dan signifikan terhadap harga saham.

d) Dari output 4.22 diperoleh nilai $\mathrm{t}$ hitung untuk Debt to Equity Ratio (DER) adalah $-3,569$. Karena nilai -t hitung $>$-t tabel (3,569>-2,00958) maka Ho diterima. Jadi dapat disimpulkan bahwa Debt to Equity Ratio (DER) secara parsial tidak berpengaruh dan signifikan terhadap hargasaham.

e) Dari output 4.22 diperoleh nilai t hitung untuk Net Profit Margin (NPM) adalah 5,235. Karena nilai $\mathrm{t}$ hitung $>\mathrm{t}$ tabel $(5,235>$ 2,00958) maka Ho ditolak. Jadi dapat disimpulkan bahwa Net Profit Margin (NPM) secara parsial berpengaruh positif dan signifikan terhadap harga saham. 
f) Dari output 4.22 diperoleh nilai t hitung untuk Return On Asset (ROA)adalah 2,412. Karena nilai $\mathrm{t}$ hitung > $\mathrm{t}$ tabel $(2,412>$ 2,00958) maka Ho ditolak. Jadi dapat disimpulkan bahwa Return On Asset (ROA) secara parsial berpengaruh positif dan signifikan terhadap harga saham.

\section{SIMPULAN DAN SARAN}

\section{Simpulan}

1) Pembuktian pengaruh Dividen Per Share (DPS) terhadap harga saham diperoleh hasil uji $t$ statistik yang memperlihatkan nilai t hitung sebesar 0,634 dan $\mathrm{t}$ tabel sebesar 2,00958 atau $2,00958(0,634<2,00958)$ maka Ho diterima sehingga dapat disimpulkan bahwa Dividen Per Share (DPS) secara parsial tidak berpengaruh dan tidak signifikan terhadap hargasaham. Berdasarkan hipotesis mengatakan bahwa Dividen Per Share (DPS) mempunyai pengaruh positif terhadap harga saham, berdasarkan hasil pengujian, Dividen Per Share (DPS) berpengaruh positif terhadap harga saham, maka dapat disimpulkan bahwa Dividen Per Share (DPS) berpengaruh positif ditolak.

2) Pembuktian pengaruh Dividen Payout Ratio (DPR) terhadap harga saham diperoleh hasil uji $\mathrm{t}$ statistik yang memperlihatkan nilai t hitung $-0,048$. Karena nilai -t hitung < -t tabel $(-0.048<-$ 2,00958) maka Ho ditolak. Jadi dapat disimpulkan dividen payout ratio (DPR) secara parsial berpengaruh negatif dan tidak siginifikan terhadap harga saham.
Berdasarkan hipotesis mengatakan bahwa Dividen Payout Ratio (DPR) mempunyai pengaruh negatif terhadap harga saham, berdasarkan hasil pengujian, Dividen Payout Ratio (DPR) berpengaruh negatif terhadap harga saham, maka dapat disimpulkan bahwa Dividen Payout Ratio (DPR) berpengaruh negatif diterima.

3) Pembuktian pengaruh Price to book Value (PBV) terhadap harga saham diperoleh hasil uji $t$ statistik yang memperlihatkan nilai $\mathrm{t}$ hitung sebesar 6,171 . Karena nilai $\mathrm{t}$ hitung $>\mathrm{t}$ tabel $(6,171>2,00958)$ maka Ho ditolak. Jadi dapat disimpulkan bahwa Price to Book Value (PBV) secara parsial berpengaruh positif dan signifikan terhadap harga saham.Berdasarkan hipotesis mengatakan bahwa Price to book Value (PBV) mempunyai pengaruh positif terhadapharga saham. Berdasarkan hasil pengujian,Price to book Value (PBV) berpengaruh positif terhadap harga saham, maka dapat disimpulkan bahwa Price to book Value (PBV) berpengaruh positif diterima.

4) Pembuktian pengaruh Debt to Equity Ratio (DER)terhadap harga saham diperoleh hasil uji $\mathrm{t}$ statistik yang memperlihatkan nilai $\mathrm{t}$ hitung sebesar $-3,569$. Karena nilai -t hitung $>$-t tabel (3,569>-2,00958) maka Ho diterima. Jadi dapat disimpulkan bahwa Debt to Equity Ratio (DER) secara parsial tidak berpengaruh dan signifikan terhadap hargasaham. Berdasarkan hipotesis mengatakan bahwa Debt to 
Equity Ratio (DER) mempunyai pengaruh negatif terhadapharga saham. Berdasarkan hasil pengujian,Debt to Equity Ratio (DER) berpengaruh negatif terhadap harga saham, maka dapat disimpulkan bahwa Debt to Equity Ratio (DER) berpengaruh negatif diterima.

5) Pembuktian pengaruh Net Profit Margin (NPM) terhadap harga saham diperoleh hasil uji $t$ statistik yang memperlihatkan nilai $\mathrm{t}$ hitung sebesar 5,235. Karena nilai t hitung $>\mathrm{t}$ tabel $(5,235>2,00958)$ maka Ho ditolak. Jadi dapat disimpulkan bahwa Net Profit Margin (NPM) secara parsial berpengaruh positif dan signifikan terhadap harga saham. Berdasarkan hipotesis mengatakan bahwa Net Profit Margin (NPM) mempunyai pengaruh positif terhadapharga saham. Berdasarkan hasil pengujian,Net Profit Margin (NPM) berpengaruh positif terhadap harga saham, maka dapat disimpulkan bahwa $\mathrm{Net}$ Profit Margin (NPM) berpengaruh positif diterima.

6) Pembuktian pengaruh Return On Asset (ROA) terhadap harga saham diperoleh hasil uji $t$ statistik yang memperlihatkan nilai $\mathrm{t}$ hitung sebesar 2,412. Karena nilai $\mathrm{t}$ hitung $>\mathrm{t}$ tabel $(2,412>2,00958)$ maka Ho ditolak. Jadi dapat disimpulkan bahwa Return On Asset (ROA) secara parsial berpengaruh positif dan signifikan terhadap harga saham. Berdasarkan hipotesis mengatakan bahwa Return On Asset (ROA) mempunyai pengaruh positif terhadapharga saham. Berdasarkan hasil pengujian,Return On Asset
(ROA) berpengaruh positif terhadap harga saham, maka dapat disimpulkan bahwa Return On Asset (ROA) berpengaruh positif diterima.

7) Pembuktian hasil pengujian statistik yang dilakukan dapat disimpulkan bahwa secara simultan atau secara keseluruhan yaitu dividen per share, dividen payout ratio, price to book value, debt to equity ratio, net profit margin dan return on assetsecara bersama-sama (simultan) berpengaruh terhadap harga saham. Hal tersebut dapat dibuktikan dengan melihat hasil uji $\mathrm{F}$ yang bernilai 83,991. F hitung $>\mathrm{F}$ tabel $(83,991>2,29)$ maka secara bersama-sama varabel independen yaitu dividen per share, dividen payout ratio, price to book value, debt to equity ratio, net profit margin dan return on assetberpengaruh terhadap variabel dependen yaitu harga saham.

\section{Saran}

Saran yang dapat diungkapkan penulis sesuai dengan penelitian ini yaitu sebagai berikut:

1) Bagi peneliti selanjutnya sebaiknya menggunakan semua variabel yang ada pada rasio keuangan dengan beberapa indikator yang terdapat didalamnya.

2) Menggunakan objek penelitian yang lebih luas yaitu seluruh perusahaan yang listing di Bursa Efek Indonesia.

3) Menggunakan faktor-faktor eksternal yang kemungkinan mempengaruhi harga saham seperti inflasi, tingkat suku bunga, pertumbuhan ekonomi Indonesia, dan kurs valuta asing. 
4) Sebaiknya bagi pihak manajemen harus mempertimbangkan pembagian dividen kepada pemegang saham, karena dividen merupakan salah satu daya tarik investor dalam membeli saham khususnya investor jangka pendek akan tetapi perusahaan harus tetap mempertimbangkan jumlahnya dividen yang dibagikan agar tidak membebani keuangan perusahaan.

\section{DAFTAR PUSTAKA}

Ang, Robert. 1997. Buku Pintar Pasar Modal Indonesia, Media Staff, Jakarta.

Denies Priantinah dan Prabandaru Adhe Kusuma. 2012. Pengaruh Return On Investment (ROI), Earning Per Share (EPS) dan Dividen Per Share (DPS) terhadap harga saham perusahaan pertambangan yang terdaftar di Bursa Efek Indonesia (BEI) periode 20082010. Jurnal Nominal | Volume 1 Nomor 1 | Tahun 2012 hal.1-15. Universitas Negeri Yogyakarta.

Diah Prameswari D. 2014. Pengaruh Return On Asset (ROA), Net Profit Margin (NPM), dan Earning Per Share (EPS) terhadap Harga Saham pada perusahaan sektor telekomunikasi yang terdaftar di Bursa Efek Indonesia. Jurnal Ilmiah Mahasiswa Manajemen (JIM-MNJ) Vol. 1 No. 4, Oktober 2014.

Djonysan. 2014. Pengaruh Earnng Per Share (EPS) dan Dividen Per Share (DPS) Terhadap Harga Saham pada Perusahaan Manufaktur yang Terdaftar di Bursa Efek Indonesia (BEI). Jurnal Ilmiah Mahasiswa Akuntansi (JIMA) Vol. 1 No. 1, Januari 2014.

Edhi Asmirantho. 2014. Effect of Financial Fundamental Factors And Macroeconomics to Stock
Return with Implications on Corporate Value (Tobin's Q) Real Estate and Property Go Public in Indonesia. Jurnal of Business and Management (JOBMAN), Vol. 1 No. 1, Januari 2014. ISSN : 23551240.

Eduardus, Tandelilin. 2001. Analisis Investasi dan Manajemen Portofolio, BPFE, Yogyakarta.

Eugene F, Brigham and Joel F. Houston. 1999. Manajemen Keuangan, Erlangga,

Jakarta.

Eugene F, Brigham and Joel F. Houston. 2006. Dasar- Dasar Manajemen Keuangan. Edisi 10 Buku 1, Salemba Empat, Jakarta.

H. M. Jogiyanto. 2000. Teori Portofolio dan Analisis Investasi, Edisi 2, BPFE, Yogyakarta.

James M. Reeve. S. Warren, Carl. et.al. 2010. Pengantar Akuntansi AdaptasiIndonesia. Jakarta: Salemba Empat.

Keown J. Arthur dan Scott David F. 2000. Dasar-dasar Manajemen Keuangan, Salemba Empat, Jakarta.

Meilinda, Haryuningputri.\& Tri Widyarti, Endang. 2012. Pengaruh Rasio Profitabilitas dan Eva Terhadap Harga Saham Pada Sektor Industri Manufaktur di BEI. Jurnal Ilmiah Manajemen.Vol 1. No.2. Tahun 2012. Hal. 67-79. Universitas Diponegoro. Semarang.

Putu Dina Aristya Dewi dan I.G. N. A. Suaryana (2013) pengaruh EPS, DER, dan PBV terhadap harga saham. E-Jurnal Akuntansi Universitas Udayana. ISSN : 2302-8556.

Rescyana Putri Hutami. 2012. Pengaruh Dividend Per Share, Return On Equity dan Net ProfitMarginTerhadap Harga 
Saham Perusahaaan Industri Manufaktur Yang Tercatat DiBursa Efek Indonesia Periode 2006-2010.Jurnal Volume I Nomor I. Tahun 2012. Universitas Negeri Yogyakarta.

Stella. 2009. Pengaruh price to earnings ratio, debt to equity ratio, return on asset dan price to book value terhadap harga saham. Jurnal Bisnis dan Akuntansi. Vol. 11, No.2, Agustus 2009, Hlm. 97-106.

Syahib Natarsyah. 2000. Analisis pengaruh beberapa faktor fundamental dan resiko sistematik terhadap harga saham (Kasus industri barang konsumsi yang go public di pasar modal indonesia). Jurnal Ekonomi dan Bisnis Indonesia. Vol 15. No. 3. Tahun 2000.

Van Horne, C James dan John M. Wachowicz, Jr. 1998. Fundamentals of Financial Management, Prentice-Hall, New Jersey.

Wild, Jhon W., K. R. Subramanyam dan Robert F. Halsey yang dialih bahasa oleh Yavini dan Harahap. 2005. Financial Statement Analysis, Edisi 8, Salemba Empat, Jakarta.

www.idx.co.id 